J. Biosci., Vol. 4, Number 2, June 1982, pp.227-237 ～C Printed in India.

\title{
Induction of riboflavin-carrier protein in the immature male rat by estrogen: kinetic and hormonal specificity
}

\author{
C. V. RAMANA MURTY and P. R. ADIGA \\ Department of Biochemistry, Indian Institute of Science, Bangalore 560012 \\ MS received 3 March 1982
}

\begin{abstract}
The kinetics of estrogen-induced accumulation of riboflavin-carrier protein in the plasma was investigated in immature male rats using a specific and sensitive homologous radioimmunoassay procedure developed for this purpose. Following a single injection of the steroid hormone, plasma riboflavin-carrier protein levels increased markedly after an initial lag period of approximately $24 \mathrm{~h}$, reaching peak levels around $96 \mathrm{~h}$ and declining thereafter. A 1.5 fold amplification of the inductive response was evident on secondary stimulation with the hormone. The magnitude of the response was dependent on hormonal dose, whereas the initial lag phase and the time of peak riboflavin-carrier protein induction were unaltered within the range of the steroid doses $(0.1-10 \mathrm{mg} / \mathrm{kg}$ body wt.) tested. Simultaneous administration of progesterone did not affect either the kinetics or the maximum level of the protein induced. The hormonal specificity of this induction was further adduced by the effect of administration of antiestrogens viz., En and $\mathrm{Zu}$ chlomiphene citrates, which effectively curtailed hormonal induction of the protein. That the induction involved de novo-protein synthesis was evident from the complete inhibition obtained upon administration of cycloheximide. Passive immunoneutralization of endogenous riboflavin-carrier protein with antiserum to the homologous protein terminated pregnancy in rats confirming the earlier results with antiserum to chicken riboflavin-carrier protein.
\end{abstract}

Keywords. Riboflavin carrier protein; radioimmunoassay; estrogen induction; specificity; kinetics;amplification; antiestrogens; secondary stimulation; immunoneutralization; pregnancy termination.

\section{Introduction}

In the chicken (and presumably in other oviparous species also), adequate deposition in the egg of water-soluble vitamins like riboflavin (Rhodes et al., 1959; Murty and Adiga, 1977), thiamin (Muniyappa and Adiga, 1981), biotin(Eakin et al., 1940; White et al., 1976; Murthy and Adiga, 1980) etc. for utilisation by and proper development of the prospective embryo, is accomplished by the obligatory participation of the high-affinity carrier proteins specific to each of these vitamins. Earlier, we showed that all these egg proteins are inducible specifically by estrogen (Murty and Adiga, 1978; Muniyappa and Adiga, 1980a; Ramana Murty and Adiga, unpublished) either in the adult male or immature animals of either sex.

Abbreviations used: RCP,riboflavin-carrier protein; TCP, thiamine carrier protein; BCP, biotin carrier protein. 
Notwithstanding the marked difference in the patterns of embryonic development in the oviparous species vis-a-vis the mammals, we could demonstrate recently that in the pregnant rat also, a similar gestation-specific, high-affinity carrier-protein with immunological cross-reactivity to the purified chicken riboflavin-carrier protein (RCP), mediates the transplacental transport and foetal accumulation of riboflavin (Muniyappa and Adiga, 1980b; Murty and Adiga, 1981). The rodent RCP was purified to homogeneity (Muniyappa and Adiga, 1980c) and its functional importance in foetal development demonstrated. For example, it was shown that immunoneutralisation of this maternal protein in the pregnant rat by specific antiserum to chicken RCP precipitates acute flavin deficiency in the developing conceptus with a resultant marked foetal wastage followed by termination of pregnancy (Murty and Adiga, 1981). During attempts to understand the endocrine basis of the elaboration of this protein in the rat, we found using heterologous radioimmunoassay, that RCP levels in the cycling female rats were modulated in synchrony with the changing estrogen levels and that the steroid hormone could induce this protein de novo in ovarectomised female rats (Muniyappa and Adiga, 1980b). In the present paper, we report a homologous radioimmunoassay for estimating RCP and provide information on the kinetics of its induction by estradiol-17 $\beta$ in the immature male rat in response to both primary and secondary stimulation as well as the influence of specific hormonal antagonists and other factors thereon. Availability for the first time of the potent antiserum to the rodent protein prompted a reinvestigation of the effect of passive immunoneutralisation of RCP on the course of pregnancy in this mammal.

\section{Materials and methods}

Thirty day old male rats (Wistar) of our Institute Colony were fed a pelleted diet (Hindustan Lever Products, Bombay) and water ad libitum and exposed to a 14h:10h light-dark schedule. The purification of RCP from pregnant rat serum was accomplished according to the published procedure (Muniyappa and Adiga, 1980c). The antiserum against the purified rat RCP was raised in rabbits by subcutaneous injections of the protein $(100 \mu \mathrm{g})$ emulsified with Freund's complete adjuvant, once in a week, for 3 weeks followed by a booster dose of the protein $(200$ $\mu \mathrm{g}$ ) in saline. A week after the booster, blood was collected through the ear vein, and the serum prepared and kept frozen at $-20^{\circ} \mathrm{C}$. $\mathrm{Na}{ }^{125} \mathrm{I}$ for iodination of the protein, was purchased from the Radiochemical Centre, Amersham, Bucks, U.K. The sources of other chemicals and reagents were the same as described earlier (Muniyappa \& Adiga, 1980). The female rats used in passive immunoneutralisation experiments were 80-100 day old, and day 1 of pregnancy was the day on which the sperms were detected in the vaginal smear. Antiserum $(0.5 \mathrm{ml})$ was injected intraperitoneally on the 11th day of pregnancy, after inactivating the complement in the serum by warming in a water bath at $52^{\circ} \mathrm{C}$ for 5 minutes. Laprotomy was performed on day 8 to count the number of implantation sites on their uterine horns. Hormones and antiestrogens in propane-1,2-diol were injected intramuscularly, whereas cycloheximide in $0.15 \mathrm{M} \mathrm{NaCl}$ was administered intraperitonially. 


\section{Homologous radioimmunoassay for riboflavin carrier protein}

The iodination of RCP was carried out at $4^{\circ} \mathrm{C}$ by the procedure of Greenwood et al. (1963). Briefly, $2.5 \mu \mathrm{g}$ of the protein in $25 \mu \mathrm{l}$ of $100 \mathrm{mM}$-sodium phosphate buffer, $\mathrm{pH} 7.2$ was treated for $45 \mathrm{~s}$ with $0.25 \mathrm{mCi}$ of carrier-free $\mathrm{Na}{ }^{125} \mathrm{I}$ in the presence of $25 \mu \mathrm{l}$ of chloramine $\mathrm{T}(1 \mathrm{mg} / \mathrm{ml})$ and the iodination was terminated with the addition of $25 \mu \mathrm{l}$ of sodium metabisulphite $(10 \mathrm{mg} / \mathrm{ml})$. The iodinated protein was separated from the free iodine using a column $(0.6 \mathrm{~cm} \times 20 \mathrm{~cm})$ of Sephadex G75 pre-equlibrated with $0.15 \mathrm{M} \mathrm{NaCl}$ in $10 \mathrm{mM}$-sodium phosphate buffer, $\mathrm{pH} 7.5$ containing $0.5 \%(\mathrm{w} / \mathrm{v})$ gelatin. The presence of gelatin ensured the complete recovery of the protein from the column. Small portions $(25 \mu l)$ from each fraction $(1 \mathrm{ml})$ were counted for radioactivity in a gamma counter (Packard Autogamma, Model 2002). The iodinated protein was stored frozen in small batches in the presence of $2 \%(\mathrm{w} / \mathrm{v})$ bovine serum albumin until use.

\section{Immunoassay procedure}

An antiserum dilution capable of binding $25-40 \%$ of the labelled protein was selected. The assay was performed in glass tubes (Moudgal and Madhwaraj, 1974) at $37^{\circ} \mathrm{C}$ in a water bath. Rat RCP (1-200 ng) standards duplicates, and 0.05-0.1 ml portions of unknown samples were incubated with antiserum $(0.1 \mathrm{ml})$ along with non-immunised rabbit serum as controls, for 10-12 h. Labelled protein (Ca 50,000 cpm) was added to all the tubes and the incubation was continued for another $12 \mathrm{~h}$ and the antigen-antibody complex was precipitated by the double-antibody method (Murthy and Adiga, 1978) in the presence of a carrier viz. $0.1 \mathrm{ml}$ of 1:50 diluted normal rabbit serum. The precipitate was sedimented by centrifugation at $2000 \mathrm{~g}$ for $20 \mathrm{~min}$ and the radio activity measured. The amounts of RCP in the unknown samples were calculated by extrapolation from the standard curve (figure 1) that was constructed using various known amounts of unlabelled protein

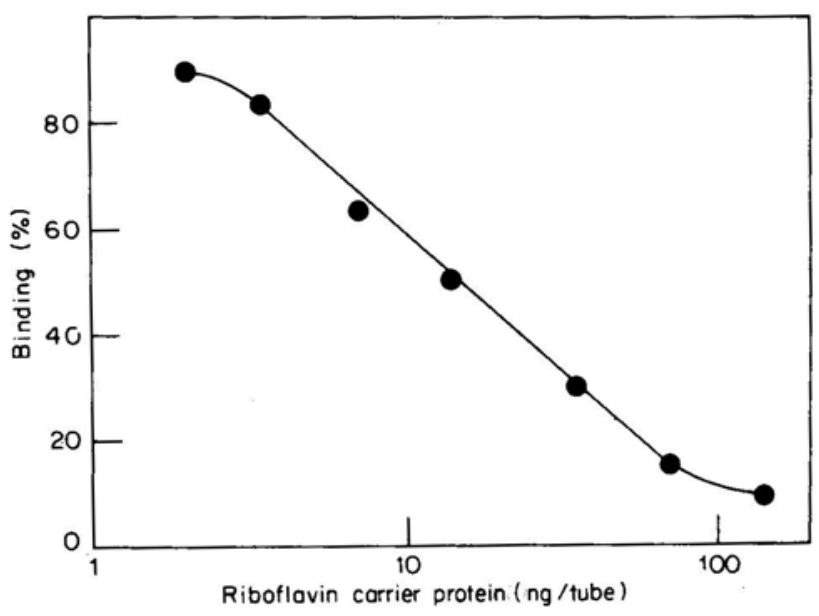

Figure 1. Standard curve for the radioimmunoassay for rat riboflavin carrier protein. The dilution of the antiserum used was 1:5000. For other details see the text. 
to inhibit the binding of the labelled protein. The total bound radioactivity in the protein refers to the amount of specifically-bound radioactivity in the absence of unlabelled protein. The non-specific binding (to non-immunised rabbit serum) was $5-10 \%$ of the total input radioactivity and this was always subtracted.

\section{Inter assay and intra assay variations:}

Aliquot from a single pooled serum sample was analysed 4-8 times for intra-assay and 4 times for inter-assay variation and the data were analysed statistically (Mulholland \& Jones, 1968). Coefficients of intra and inter-assay variations were $2-6 \%$ and $3-5 \%$ respectively and the assay method had a sensitivity of $3.5 \mathrm{ng} /$ tube. The homologous radio-immunoassay reported here had approximately 2 fold higher sensitivity compared to the earlier heterologous radioimmunoassay (Muniyappa and Adiga, 1980b).

\section{Results}

The preliminary evidence (Muniyappa \& Adiga, 1980b) that the rat RCP, like its avian counterpart, is inducible in the mammalian liver by estrogen was based on the measurement of circulating levels of this protein in the steroid-treated overectomized female rats using a heterologous radioimmunoassay which reflected only the relative concentrations of the protein in the plasma. To assess the absolute content of this vitamin-carrier following estrogenization, a sensitive radioimmunoassay was evolved after the purified rat RCP and its specific antiserum became available. Having accomplished this, a detailed investigation of the time course of accumulation of this protein in the plasma after hormonal dosing was undertaken. The time-course of accumulation and disappearance of RCP during both primary and secondary stimulations with the steroid $(10 \mathrm{mg} / \mathrm{kg}$ body weight) in 30-day old male rats is depicted in figure 2 . The plasma levels of the vitamin-carrier measured prior to hormone treatments represented the respective base-line values which were low (30-50 ng/ml). The increments, if any, in these

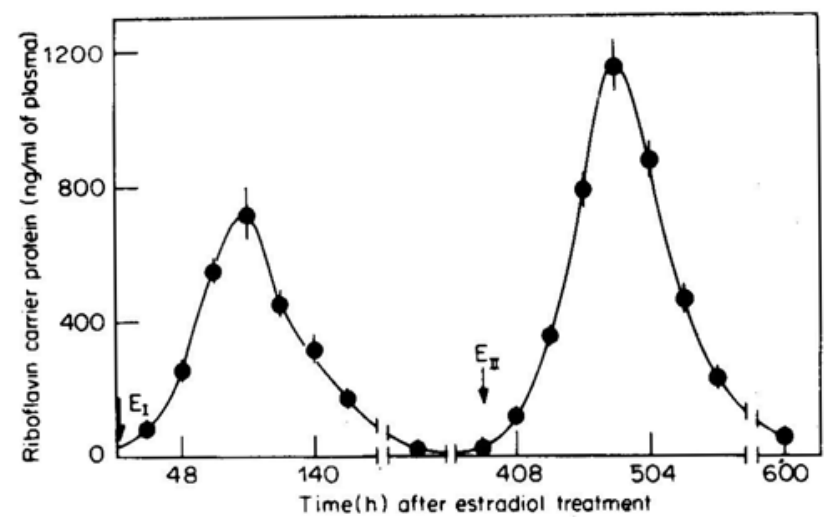

Figure 2. Time course of accumulation of riboflavin carrier protein in the plasma after sequential injections $\left(E_{I}, E_{I I}\right)$ of oestradioi-17 $\beta$ in propane-1,2-diol $(10 \mathrm{mg} / \mathrm{kg}$ body wt). The values represent means and vertical bars represent S.D. $(n=5)$. 
levels were not significant for nearly $24 \mathrm{~h}$ after estrogen treatment. Beyond this initial lag period, the RCP concentrations rose gradually with time reaching a peak value of approximately $750 \mathrm{ng} / \mathrm{ml}$ at around $96 \mathrm{~h}$ in conformity with the earlier data (Muniyappa and Adiga, 1980b). This was followed by a steady decline and by day 10 , the levels returned to the preinjection base-line values.

Sixteen days after withdrawal of the steroid, when the same animals were again challenged with a second dose of estradiol-17 $\beta \quad(10 \mathrm{mg} / \mathrm{kg}$ body weight $)$ the circulating concentration of RCP exhibited a similar kinetic pattern except that the response was considerably magnified; in fact, a typical 'memory effect' observed earlier during the elaboration of vitellogenin (Gruber et al., 1976), RCP (Murthy and Adiga, 1978), thiamine-carrier protein (Muniyappa and Adiga, 1980a) and biotin-carrier protein (Ramana Murty and Adiga, unpublished observations) in estrogen treated chicken liver was clearly evident. During this secondary stimulation, the amplification of the estrogenic response in terms of RCP induction was more than 1.5 fold. Though the peak plasma concentration of RCP was enhanced by a similar order of magnitude during the secondary stimulation, the time-course of accumulation and disappearance of the protein in circulation exhibited qualitatively the same pattern following the two hormonal stimuli. However, a comparison of the slopes of the respective ascending phases of RCP accumulation clearly shows that the rate of induction, especially during early phases, is significantly enhanced after secondary stimulation vis-a-vis primary stimulation.

\section{Hormonal dose-dependency and time-course of RCP elaboration during primary stimulation}

Varying doses of estradiol-17 $\beta$ were administered to young male rats during the primary stimulation to quantify the corresponding changes in the rates and the magnitudes of plasma accumulation and disappearance of RCP. It is evident from figure 3 that as low a dose as $100 \mu \mathrm{g} / \mathrm{kg}$ body weight (i.e., less than $10 \mu \mathrm{g} / \mathrm{animal}$ ) of the steroid could induce a measurable response which progressively increased with the hormonal dose. However, the time taken to reach the maximal protein levels following hormonal dosing remained the same within the range of the steroid dosage tested (0.1-10 $\mathrm{mg} / \mathrm{kg}$ body weight). But the rates of accumulation and disappearance from circulation as well as the peak levels reached exhibited a dosedependent phenomenon.

\section{Influence of cycloheximide}

One possibility that the rapid accumulation of RCP in the plasma after hormone administration, merely reflects an interference with the altered metabolic clearance rate and not necessarily de novo synthesis was tested by administration of cycloheximide, a powerful inhibitor of protein synthesis. When this (drug was injected intraperitoneally $(0.8 \mathrm{mg} / \mathrm{kg}$ body weight $) 30$ minutes prior to steroid administration a drastic decrease in RCP levels was observed at $72 \mathrm{~h}$, i.e., at a time when many fold increase in RCP concentration was otherwise encountered (table 1). 


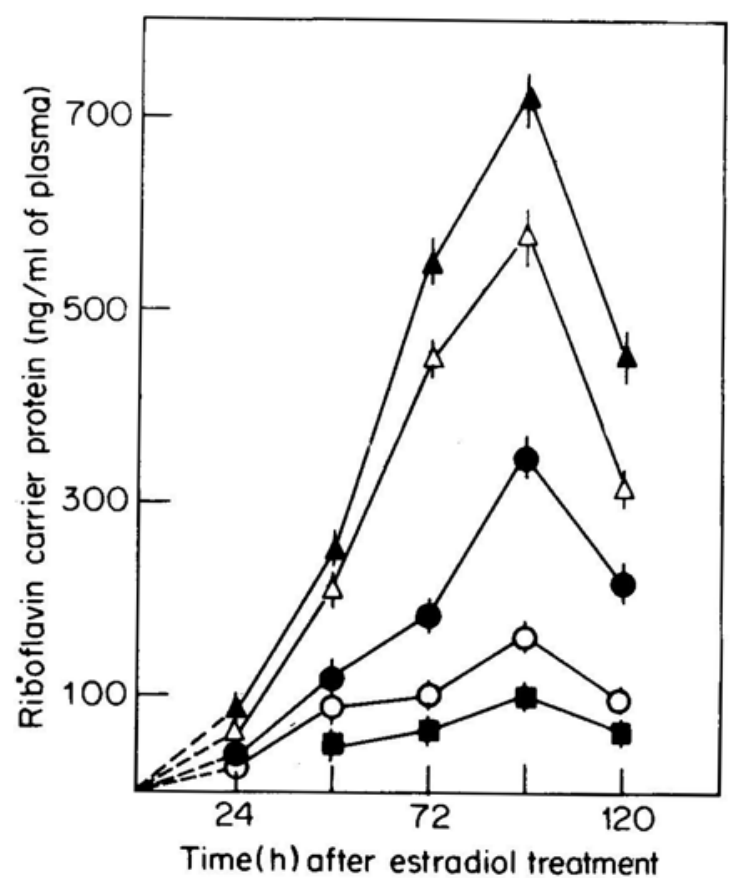

Figure 3. Hormonal dose-dependent reponse of the plasma riboflavin carrier protein during primary stimulation. Time course of plasma riboflavin carrier protein accumulation with increasing concentrations of oestradiol- $17 \beta$ (mg/kg body wt.): $\mathbf{\square}, 0.1 ; 0,0.5 ; \bullet, 1 ; \Delta, 5.0 ; \mathbf{\Lambda}$, 10.0. The values represent means and vertical bars represent S.D. $(n=5)$.

Table 1. Effect of administration of cycloheximide on estradiol-induced riboflavin carrier protein accumulation in the plasma.

\begin{tabular}{lc}
\hline $\begin{array}{c}\text { Treatment } \\
(\mathrm{mg} / \mathrm{kg} \text { body wt })\end{array}$ & $\begin{array}{c}\mathrm{ng} \mathrm{RCP} / \mathrm{ml} \text { plasma } \\
\text { at } 72 \mathrm{~h}\end{array}$ \\
\hline Control & $25 \pm 8$ \\
Estradiol $(10)$ & $480 \pm 84$ \\
Estradiol + cycloheximide $(0.8)$ & $32 \pm 6$ \\
Cyclohexiinide $(0.8)$ & $29 \pm 10$ \\
\hline
\end{tabular}

Cycloheximide $(0.8 \mathrm{mg} / \mathrm{kg}$ body wt $)$ was administered intraperitoneally $30 \mathrm{~min}$ prior to injection of estradiol $17 \beta$ and plasma riboflavin-carrier protein levels estimated at $72 \mathrm{~h}$ after estrogenisation. Data expressed as means \pm S.D. $(n=4)$.

\section{Effect of progesterone and antiestrogens}

Earlier observations with the chicken oviduct system that there exists an antagonism between estrogen and progesterone in terms of ovalbumin induction 
during primary stimulation (Palmiter and Wren, 1971) could not be demonstrated with the estrogenized chicken liver system elaborating RCP, thiamine- and biotincarrier proteins (Murty and Adiga, 1978; Muniyappa and Adiga, 1980a, Ramana Murty and Adiga, unpublished results). It was therefore of interest to investigate whether RCP induction in rat by estradiol is modulated by progesterone administered either alone or in combination with estradiol. From the data of figure 4 , it is unequivocally clear that progesterone did not exhibit any discernible influence on the kinetics of estrogen-induced RCP production in the rodent with regard to either the initial lag phase or the subsequent rates of RCP accumulation and decay in the circulation or the peak levels of the protein reached at around $96 \mathrm{~h}$ after estradiol treatment.

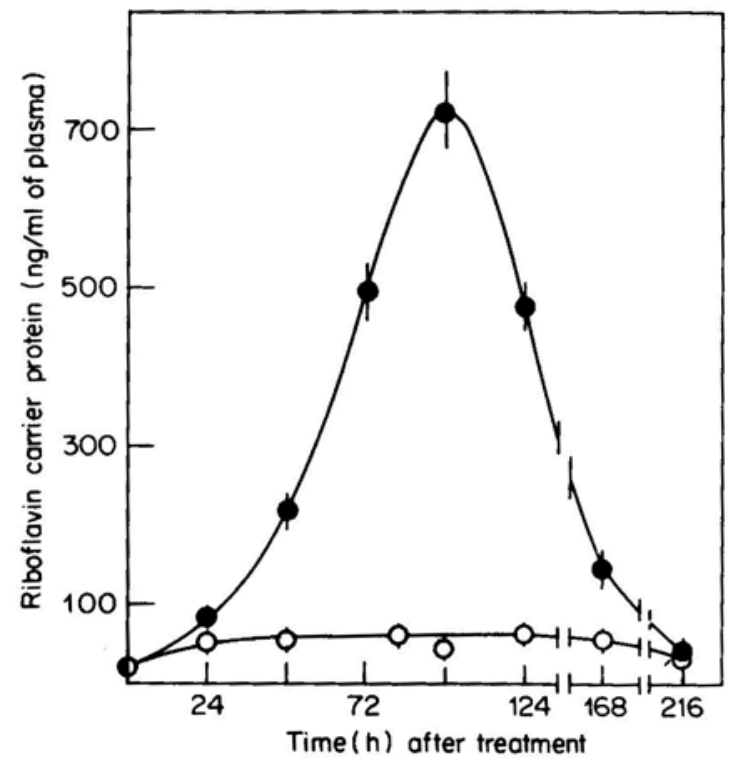

Figure 4. Time course of appearance of riboflavin carrier protein in the plasma on treatment with estradiol-17 $\beta$ (10 mg/kg body wt) + progesterone $(10 \mathrm{mg} / \mathrm{kg}$ body wt $)(\bullet)$, and progesterone $(10 \mathrm{mg} / \mathrm{kg}$ body $\mathrm{wt})$ alone $(\mathrm{O})$.

The values represent means and the vertical bars represent S.D. $(n=5)$.

In order to further substantiate this hormonal specificity of RCP induction in the rat, the potent antiestrogens viz., En- and Zu-clomiphene citrates were administered to the animals $30 \mathrm{~min}$ prior to the estrogen treatment and the plasma RCP levels were quantified at $72 \mathrm{~h}$. From the results presented in table 2, it is clear that both the antiestrogens have effectively curtailed the estrogenic response besides being ineffective by themselves to elicit even weak estrogen-like activity with regard to RCP induction.

Passive immunoneutralization with homologous antiserum and effect on pregnancy progression in the female rats -

The previous observation (Muniyappa and Adiga, 1980b) that RCP is vitally involved in transplacental flavin transport to supply vitamin to the growing 
Table 2. Influence of antiestrogens on the estradiol-17 $\beta$ stimulated plasma riboflavin carrier protein content.

\begin{tabular}{|c|c|c|}
\hline \multirow{2}{*}{$\begin{array}{l}\text { Anti estrogens } \\
\text { (mg/kg body wt.) }\end{array}$} & \multicolumn{2}{|c|}{$\begin{array}{c}\text { ng RCP } / \mathrm{ml} \text { plasma } \\
\text { at } 72 \mathrm{~h}\end{array}$} \\
\hline & $-E_{2}$ & $+E_{2}$ \\
\hline Control (none) & $15 \pm 6$ & $510 \pm 94$ \\
\hline $\begin{array}{l}\text { E Clomiphene } \\
\text { citrate (10) }\end{array}$ & $23 \pm 5$ & $58 \pm 15$ \\
\hline $\begin{array}{l}\text { Z-Clomiphene } \\
\text { citrate (10) }\end{array}$ & $21 \pm 10$ & $69 \pm 12$ \\
\hline
\end{tabular}

En- and Zu-clomiphene citrates $(10 \mathrm{mg} / \mathrm{kg}$ body wt) were administered $30 \mathrm{~min}$ prior to estradiol-17 $\beta$ administration and plasma riboflavin carrier proteins were estimated at $72 \mathrm{~h}$ after estrogenisation. Data are expressed as means \pm S.D. $(n=4)$.

foetuses, was based on the observation that passive immunoneutralisation with the antiserum to the chicken RCP led to foetal wastage followed by termination of pregnancy. With the availability of a potent antiserum to the homologous protein, it was desirable to study the influence of neutralization of endogenous RCP by this antiserum on the progression of pregnancy in the rodent. The data of table 3

Table 3. The influence of the specific antiserum to the rat riboflavin carrier protein on pregnant rats.

\begin{tabular}{lcccl}
\hline Treatment & $\begin{array}{c}\text { No. of } \\
\text { animals }\end{array}$ & nT/T & Autopsy on day 18 & Remarks \\
\hline NRS treated & 5 & $40 / 8$ & $40 / 8$ & Normal \\
A/s to ovomucoid & 5 & $48 / 9.6$ & $47 / 9.4$ & $\begin{array}{l}\text { Normal } \\
\text { A/s to rat RCP }\end{array}$ \\
& 5 & $43 / 8.6$ & $0 / 0$ & $\begin{array}{l}\text { Slight vaginal } \\
\text { bleeding during } \\
24-48 \text { h. }\end{array}$ \\
$\begin{array}{l}\text { A } / \mathrm{s} \text { to rat RCP } \\
\text { neutralised with }\end{array}$ & & & & No bleeding \\
rat RCP & 5 & $51 / 10.2$ & $50 / 10$ & Normal pups \\
\hline
\end{tabular}

The pregnant rats (11 day) were treated with either the non-immune rabbit serum (NRS) $(0.5$ $\mathrm{ml}$ ), or ovomucoid antiserum or antiserurm to the purified rat riboflavin carrier protein raised in rabbits $(0.5 \mathrm{ml} /$ rat $)$. $\mathrm{nT}=$ total number of implantation sites; $\mathrm{T}=$ average implantation sites/ animal determined at laprotomy. The sera were incubated at $52^{\circ} \mathrm{C}$ for $5 \mathrm{~min}$ to inactivate the complement and were administered intraperitoneally. $\mathrm{A} / \mathrm{S}=$ antiserum.

provide unequivocal evidence that intraperitoneal administration to pregnant rats of adequate quantities of the antiserum to the homologous RCP on day 11 of gestation proved deleterious and resulted in $100 \%$ termination of pregnancy within 
24-28h after antiserum administration. It was also found that this phenomenon was preceded by slight vaginal bleeding in these animals. In contrast, pregnant animals treated with either non-immunised rabbit serum or with antiserum to a highly immunogenic protein viz. ovomucoid were unaffected in terms of suppression of pregnancy.

\section{Discussion}

Consistent with our earlier observations with ovarectomised female rats (Muniyappa and Adiga, 1980b), the data presented above amply substantiate that a single injection of estradiol-17 $\beta$ induces RCP in a dose-dependent manner in immature male rats as well. A comparison of these kinetic data with those obtained earlier with chicken (Murthy and Adiga, 1978) reveal several interesting similarities in the induction of RCP in the two species of animals. Quantitatively, these extend from initial lag phase during which no significant protein accumulates in the plasma, through the patterns of rapid rise and decay in plasma concentrations during primary induction, to significant amplification of the inductive response during secondary stimulation with the steroid. Quantitatively, however, the rodent liver responding to the hormone in terms of RCP induction seems kinetically more sluggish as judged from the relatively protracted initial lag phase (of nearly $24 \mathrm{~h}$ compared to 4-5 $\mathrm{h}$ in the chicken,(Murthy and Adiga, 1978), an extended duration of both ascending and descending phases and relatively lower magnitude of amplification during secondary stimulation. Nonetheless, overall similarity in the pattern of RCP induction in the two species is clearly evident. That the underlying mechanism may also be analogous is supported by the finding, that as in the chicken liver (Lazier \& Haggarty, 1979), specific, high-affinity cytoplasmic estrogen receptors capable of rapid nuclear translocation and functional interaction with chromatin acceptor sites exist in hepatocytes of both the male and female rats (Atew et al., 1978) and that hormone administration brings about marked changes in the composition and function of the mammalian liver (Seal and Doe, 1969).

The characteristic 'memory effect' with attendant amplification of the inductive response (figure 2) seen during secondary stimulation with the hormonal steroid has also been observed earlier with the estrogenised liver synthesizing RCP (Murthy and Adiga, 1978), TCP (Muniyappa and Adiga, 1980a) biotin binding protein (Ramana Murty and Adiga, unpublished observation) and in chicken (Gruber et al., 1976) and amphibian (Tata, 1976) liver systems elaborating vitellogenin. Though the intricacies of exact molecular mechanism involved need further elucidation, more pronounced transcription presumably due to permanent changes in chromatin (Jost et al., 1978) and rapid translation due to stabilization of mRNAs during this period have been definitely established as dominant parameters responsible for more efficient induction of these proteins. Furthermore, recent investigations with X. laevis (Hayward et al., 1981) have shown that enhanced synthesis as well as marked redistribution of available estrogen receptors between nuclear and cytoplasmic components of the hepatocytes with resultant availability of relatively more cytoplasmic receptors for rapid nuclear translocation of the hormone during secondary stimulation may also be an important contributory factor in this regard. Whatever the underlying mechanism, it is clear from the 
results of figure 2 that the amplification of estrogen-induced specific gene expression during secondary stimulation is not confined to oviparous species, but extends to mammals also. The only other instance of this kind demonstrated hitherto in mammals is related to enhanced production of prolactin mRNA (but not its translation product) in the pituitary of male rats repeatedly treated with estrogen (Seo et al., 1979). However, it is pertinent to point out that prolactin, unlike RCP, is a normal constituent and secretory product of the pituitary tissue and that the steroid only enhances the expression of its gene and does not induce its synthesis de novo.

It is now well documented that estrogen administration brings about the modulation of synthesis of several plasma proteins in the mammalian liver (Seal and Doe, 1969); the plasma renin substrate is notable among these in that its levels can be enhanced by the steroid hormone in a dose-dependent manner in the adult rat though not in prepubertal rats, which have limited population of hepatic estradiol receptors available at this stage (Dickson and Eisenfeld, 1979). The reasons for age-dependant difference in inducibility between plasma rennin substrate and RCP are not clear at present. It may be related to the fact that different threshold concentrations of estrogen-receptor complex may be needed at nuclear chromatin acceptor sites for the induction of different proteins (Palmiter, et al., 1981). Based on this premise, it is reasonable to surmise that relatively lower levels of estrogen-receptors available in prepubertal rat liver are sufficient to induce RCP, but not plasma renin substrate. The proof of this hypothesis however awaits further study.

Another intriguing facet of analogy between the rat and the chicken systems with regard to RCP induction is the hormonal specificity as exemplified by complete lack of response to progesterone, either alone or in combination with estrogen (figure 4). Further support for this specificity stems from the data in table 2 regarding complete blockade of RCP induction by anti-estrogens. Again as opposed to the findings with rat uterus (Mohla and Prasad, 1969) these antihormones failed to exhibit any descernible estrogen-like activity by themselves in terms of $\mathrm{RCP}$ induction in the rodent liver.

From the foregoing, it is clear that despite marked differences between the rat and the oviparous species in the patterns of embryonic development, the carrierprotein-mediated vitamin delivery mechanism is conserved during evolution of species. The similarity is not only in some structural and functional features of the carrier protein but also with respect to the pattern of hormonal inducibility in the liver. Since the data of table 3 clearly reinforce the earlier postulation that RCP is vitally concerned with embryonic development in both the species (Muniyappa and Adiga, 1980b; Murty and Adiga, 1981), it is clear that estrogen-induced specific protein synthesis in mammalian liver is not merely an evolutionary vestige and that in the female mammal some of these proteins may have an important function during pregnancy as nutrient carriers for embryonic development. Viewed from this angle, it would appear that the mammalian liver, like its avian counterpart (Gruber et al., 1976) can also be considered as an accessory sex organ. 


\section{Acknowledgements}

Financial assistance from the Indian Council of Medical Research, New Delhi is gratefully acknowledged. Our thanks are due to Prof. N. R. Moudgal for helpful discussions and for providing facilities for radioimmunoassay.

\section{References}

Atew. R. F., Weinberger, M. J. and Eisenfeld, A. J. (1978) Endocrinology. 102, 433.

Dickson. R.B. and Eisenfeld, A. J. (1979) Biol. Rep., 21, 1105.

Eakin, R. E.. Shell. E. E. and Williams, R. J. (1940) J. Biol. Chem., 136, 801.

Greenwood, F. C, Hunter. H. M. and Glover, J.S. (1963) Biochem. J.. 89, 114.

Gruber, M., Bos. E. S. and AB. G. (1976) Mol. Cell Endocrinol., 5, 41.

Hayward, M. A., Mitchell, T. A. and Shapiro, D. J. (1981)J. Biol. Sci., 255, 11308.

Jost. J. P.,Ohno, T., Panyim, S. and Schuerch, A. R. (1978) Eur. J. Biochem., 84, 355.

Lazier, C. B. and Haggarty, A. J. (1979) Biochem. J., 180, 347.

Maw, A. J. G. (1954) Poult. Sci., 33, 216.

Mohla, S. and Prasad, M. R. N. (1969) Acta Endocrinol (Copenhagen), 62, 489.

Moudgal, N. R. and Madhwaraj, H. G. (1974) in Methods in Hormone Radioimmunoassay, eds. B. M. Jaffe and H. R. Behrman (New York: Academic Press) pp. 57-85.

Mulholland, H. and Jones, C. R. (1968) Fundamentals of Statistics, (London: The English Language Book Society and Butter-Worths) pp. 139-156.

Muniyappa, K. and Adiga, P. R. (1980a) Biochem. J., 186, 201.

Muniyappa, K. and Adiga, P. R. (1980b) FEBS Lett., 110, 209.

Muniyappa, K. and Adiga, P. R. (1980c) Biochem. J., 187, 537.

Muniyappa, K. and Adiga, P. R. (1981) Biochem. J., 193, 679.

Murty, C. V. R. and Adiga, P. R. and Adiga, P. R. (1980) Indian J. Biochem. Biophys., 17,102.

Murthy, C. V. R. and Adiga, P. R. (1981) FEBS Lett., 135, 281.

Murthy, U. S. and Adiga, P. R. (1977) Indian J. Biochem. Biophys., 14, 118.

Murthy, U. S. and Adiga, P. R. (1978) Biochim. Biophys. Acta, 538, 364.

Palmiter, R. D., Mulvihill, E. R., Shepherd, J. H. and McKnight, G. S. (1981)J. Biol. Chem., 256,7910.

Palmitter, R. D. and Wrenn, J. I. (1971)J. Cell Biol., 50, 598.

Rhodes, M. B., Bennet. N. S. and Feeney, R. E. (1959)J. Biol. Chem., 234, 2054.

Seal, U. S. and Doe, R. P. (1969) in Metabolic Effects of Gonadal Hormones and Contraceptive Steroids, eds. H. A. Salhanick, D. M. Kipsis and R. L. Vande (New York: Wiele-Plenum Press) pp. 277-318.

Seo, H., Refetoff, S., Vassart, G. and Brocas, H. (1979) Proc. Natl. Acad. Sci. (U.S.A.), 76, 824.

Tata, J. R. (1976) Cell, 9, 1.

White, H. B., Dennison, B. A., Ferra, M.-A.D., Whitney, C. J., McGuire, J. C, Meslar, H. W. and Sammelwitz, P. H. (1976) Biochem. J., 157, 395. 